\title{
Epidemiology of human West Nile virus infections in the European Union and European Union enlargement countries, 2010 to 2018
}

\author{
Bakonyi ${ }^{1}$, Céline $M$ Gossner $^{1}$ \\ 1. European Centre for Disease Prevention and Control (ECDC), Solna, Sweden \\ 2. These authors contributed equally to this article and share first authorship \\ 3. Center for Virology, Medical University of Vienna, Vienna, Austria \\ 4. Hellenic National Public Health Organization, Athens, Greece \\ 5. Istituto Superiore di Sanità, Rome, Italy \\ 6. Institute for Public Health of Montenegro, Podgorica, Montenegro
}

Johanna J Young ${ }^{1,2}$, Joana M Haussig ${ }^{1,2}$, Stephan W Aberle ${ }^{3}$, Danai Pervanidou ${ }^{4}$, Flavia Riccardo ${ }^{5}$, Nebojša Sekulić ${ }^{6}$, Tamás

Correspondence: Joana M. Haussig (Joana.Haussig@ecdc.europa.eu)

Background: West Nile virus (WNV) circulates in an enzootic cycle involving mosquitoes and birds; humans are accidental hosts. Aim: We analysed human WNV infections reported between 2010 and 2018 to the European Centre for Disease Prevention and Control to better understand WNV epidemiology. Methods: We describe probable and confirmed autochthonous human cases of WNV infection reported by European Union (EU) and EU enlargement countries. Cases with unknown clinical manifestation or with unknown place of infection at NUTS 3 or GAUL 1 level were excluded from analysis. Results: From southern, eastern and western Europe, 3,849 WNV human infections and 379 deaths were reported. Most cases occurred between June and October. Two large outbreaks occurred, in $2010(n=391)$ and in $2018(n=1,993)$. The outbreak in 2018 was larger than in all previous years and the first cases were reported unusually early. The number of newly affected areas $(n=45)$ was higher in 2018 than in previous years suggesting wider spread of WNV. Conclusion: Real-time surveillance of WNV infections is key to ensuring that clinicians and public health authorities receive early warning about the occurrence of cases and potential unusual seasonal patterns. Human cases may appear shortly after first detection of animal cases. Therefore, public health authorities should develop preparedness plans before the occurrence of human or animal WNV infections.

\section{Background}

West Nile virus (WNV) infection is a zoonosis endemic in many parts of Europe, apart from northern Europe. The virus is primarily transmitted through the bites of infected mosquitoes, mainly of the Culex genus, but occasionally also through transfusion/transplantation of substances of human origin (SoHO) (i.e. blood, organs or cells), percutaneous or conjunctival exposure in laboratories, or transplacental passage from mother to fetus [1].** Mosquitoes serve as vectors and birds are the main amplifying hosts [1]. Humans and other mammals, such as equids, are dead-end hosts [2]. In humans, the incubation period is usually 2-6 days, although incubation periods of up to 21 days have been reported in immunocompromised people [1]. Most humans infected with WNV remain asymptomatic, ca $20 \%$ develop influenza-like symptoms and less than $1 \%$ develop severe symptoms such as encephalitis, meningoencephalitis or meningitis [3]. Elderly and immunocompromised individuals are at higher risk of developing severe symptoms [4].

WNV lineages 1 and 2 are associated with human disease, with differences in virulence; however no clear linkage between virulence and lineage classification exists [1]. In Europe, WNV infections in humans were first detected by serological studies in Albania in 1958 $[5,6]$. A WNV strain of genetic lineage 1 was isolated for the first time in humans and mosquitoes in 1963 in the Rhône delta, France; it has since then caused sporadic cases and occasional outbreaks in animals and humans [6]. Lineage 2 was first detected in Hungary in 2004 and subsequently spread across central Europe and the eastern Mediterranean region $[7,8]$ causing major outbreaks (e.g. Greece 2010, Serbia 2012 and several European countries 2018) [9-13]. The exact origin of the strain has not been identified. The nucleotide sequences had the highest similarity to WNV isolates from sub-Saharan Africa from the 1990 s $[10,12]$. 


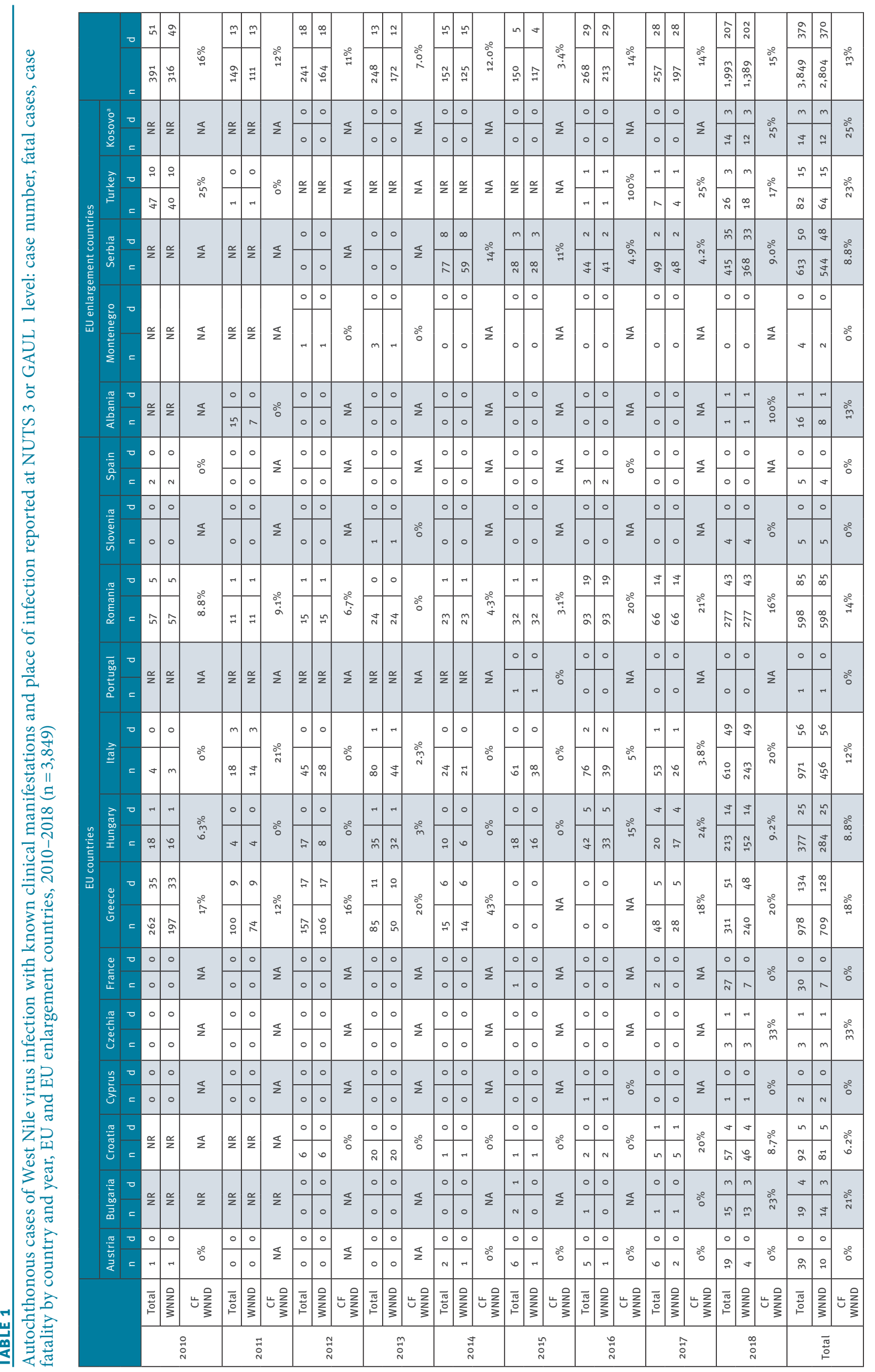


TABLE 2

Main characteristics of cases of West Nile virus infection, EU and EU enlargement countries, 2010-2018 ( $\mathrm{n}=3,849)$

\begin{tabular}{|c|c|c|c|c|c|c|c|c|c|c|}
\hline & 2010 & 2011 & 2012 & 2013 & 2014 & 2015 & 2016 & 2017 & 2018 & $2010-2018$ \\
\hline \multicolumn{11}{|l|}{ Demographics } \\
\hline Median age in years (IQR) & $\begin{array}{c}70 \\
(53-77) \\
\end{array}$ & $\begin{array}{c}70 \\
(50-77) \\
\end{array}$ & $\begin{array}{c}67 \\
(54-76) \\
\end{array}$ & $\begin{array}{c}66 \\
(51-78) \\
\end{array}$ & $\begin{array}{c}65 \\
(53-74) \\
\end{array}$ & $\begin{array}{c}63 \\
(49-74) \\
\end{array}$ & $\begin{array}{c}65 \\
(53-75) \\
\end{array}$ & $\begin{array}{c}64 \\
(51-76) \\
\end{array}$ & $\begin{array}{c}66 \\
(52-76) \\
\end{array}$ & $\begin{array}{c}66 \\
(52-76) \\
\end{array}$ \\
\hline Female: age (IQR) & $\begin{array}{c}71 \\
(58-78) \\
\end{array}$ & $\begin{array}{c}70 \\
(48-77) \\
\end{array}$ & $\begin{array}{c}68 \\
(53-77) \\
\end{array}$ & $\begin{array}{c}64 \\
(49-79) \\
\end{array}$ & $\begin{array}{c}66 \\
(53-75) \\
\end{array}$ & $\begin{array}{c}61 \\
(45-69) \\
\end{array}$ & $\begin{array}{c}69 \\
(54-77) \\
\end{array}$ & $\begin{array}{c}64 \\
(51-76) \\
\end{array}$ & $\begin{array}{c}66 \\
(50-77) \\
\end{array}$ & $\begin{array}{c}66 \\
(51-77) \\
\end{array}$ \\
\hline Male: age (IQR) & $\begin{array}{c}67 \\
(50-76) \\
\end{array}$ & $\begin{array}{c}70 \\
(52-75)\end{array}$ & $\begin{array}{c}66 \\
(54-75) \\
\end{array}$ & $\begin{array}{c}67 \\
(53-77)\end{array}$ & $\begin{array}{c}64 \\
(52-74)\end{array}$ & $\begin{array}{c}63 \\
(51-76)\end{array}$ & $\begin{array}{c}64 \\
(52-74)\end{array}$ & $\begin{array}{c}64 \\
(50-77)\end{array}$ & $\begin{array}{c}66 \\
(54-76)\end{array}$ & $\begin{array}{c}66 \\
(53-76)\end{array}$ \\
\hline Male:female ratio & 1.3 & 1.7 & 1.3 & 1.5 & 1.8 & 2.7 & 1.4 & 1.6 & 1.5 & 1.5 \\
\hline \multicolumn{11}{|l|}{ Clinical manifestation } \\
\hline$\%$ WNND & 81 & 74 & 68 & 69 & 82 & 78 & 79 & 77 & 70 & 73 \\
\hline$\%$ WNF & 19 & 25 & 32 & 30 & 18 & 12 & 12 & 16 & 26 & 24 \\
\hline$\%$ Asymptomatic cases & 0.0 & 0.67 & 0.0 & 0.40 & 0.0 & 10.0 & 8.6 & 7.0 & 4.1 & 3.6 \\
\hline \multicolumn{11}{|l|}{ Classification } \\
\hline$\%$ Confirmed cases & 50 & 66 & 52 & 73 & 81 & 86 & 89 & 77 & 86 & 78 \\
\hline
\end{tabular}

EU: European Union; IQR: interquartile range; WNND: West Nile neuroinvasive disease.

Therefore, it is hypothesised that the strain was introduced from Africa, most probably by migratory birds.

WNV infections have been notifiable at the European Union (EU) level since 2008 but only became notifiable in some EU countries at a later stage $[14,15]$. The EU countries report human cases to the European Centre for Disease Prevention and Control (ECDC) which, in turn, produces annual epidemiological summaries and, since 2011, weekly surveillance updates. Within the framework of the EU enlargement cooperation, EU enlargement countries also report human infections to ECDC. Reporting human WNV infections has been mandatory in Montenegro since 2012 and was introduced in Serbia in 2012 [16]. The main objective of timely WNV surveillance at the EU level is to provide early warning to public health professionals about areas with human WNV infections and thereby prevent human-to-human transmission via donation of contaminated SoHO. The EU blood safety directive obliges blood establishments to defer donors for 28 days after leaving an area where human cases were detected unless an individual donation nucleic acid test is negative [17].

We describe the epidemiology of WNV infections in EU and EU enlargement countries between 2010 and 2018 and raise hypotheses explaining the intensity of the transmission, the geographical spread of the virus and the seasonality of virus circulation. Finally, we highlight challenges and opportunities of strengthening WNV surveillance in Europe.

\section{Methods}

Following the EU case definition (Commission Decision $2008 / 426 / E C$ ) [18], we included probable and confirmed autochthonous human cases of WNV infection reported to the ECDC between 2010 and 2018 by EU and EU enlargement countries.

\section{Operational definitions}

Cases of WNV infection included cases with WNV neuroinvasive disease (WNND), cases with clinical signs or symptoms but without neurological manifestations (West Nile fever (WNF)) and asymptomatic cases. Cases with an unknown clinical manifestation were excluded. Autochthonous cases were individuals exposed in the reporting country during the incubation period of the infection. Asymptomatic cases were captured through blood donation screening. Affected areas were mapped at nomenclature of territorial units for statistics (NUTS) 3 level, or alternatively global administrative unit layers (GAUL) 1 level and were areas where (at least one) human autochthonous WNV infection occurred in a given year $[19,20]$. Newly affected areas were areas that were affected for the first time after 2010. Cases with an unknown place of infection at NUTS 3 or GAUL 1 level were excluded from all analyses.

\section{Data analysis}

The following variables were analysed: demographical information (e.g. age, sex), case classification (confirmed or probable), clinical manifestation (WNND, WNF or asymptomatic), date of disease onset, date of diagnosis, date of hospitalisation, date of notification, reporting country, place of infection, importation status (autochthonous or travel-related) and outcome (survival or death).

The case fatality (CF) of cases with WNND was calculated by dividing the number of deaths by the number of WNND cases in a given year. The trend analysis was based on month of disease onset. When month of onset was missing, we used the month of diagnosis 
Reported cases of West Nile virus infection by month and year of disease onset ${ }^{\mathrm{a}}$ and seasonal distribution, EU and EU enlargement countries, 2010-2018 $(\mathrm{n}=3,849)$

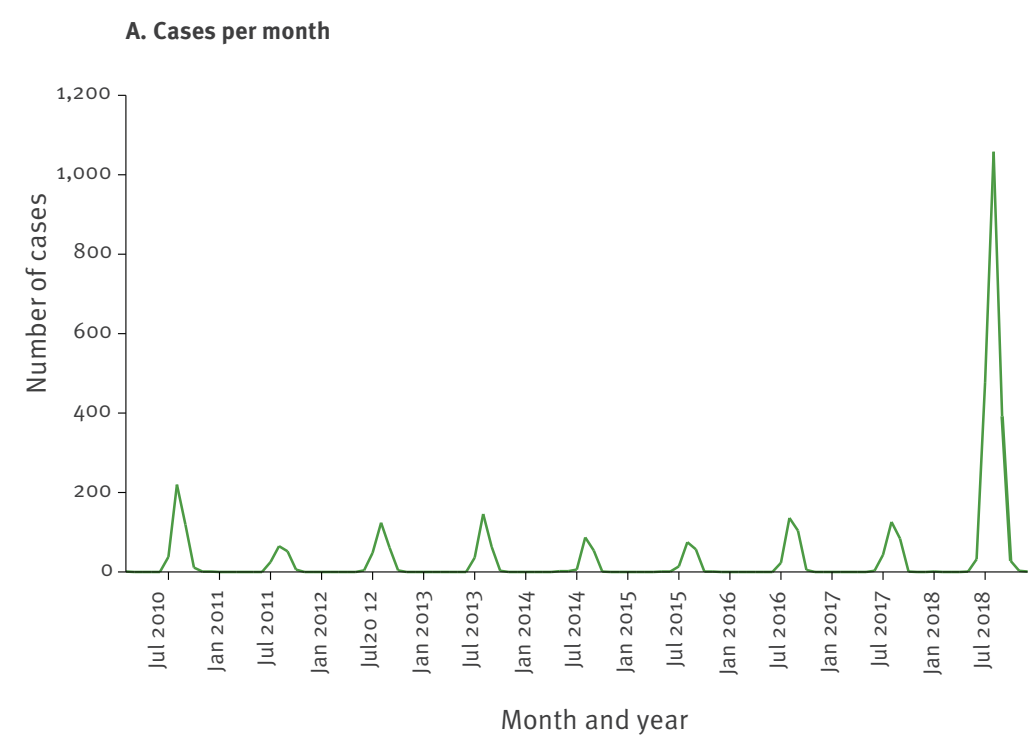

B. Seasonal distribution in 2018 compared with 2010-2017

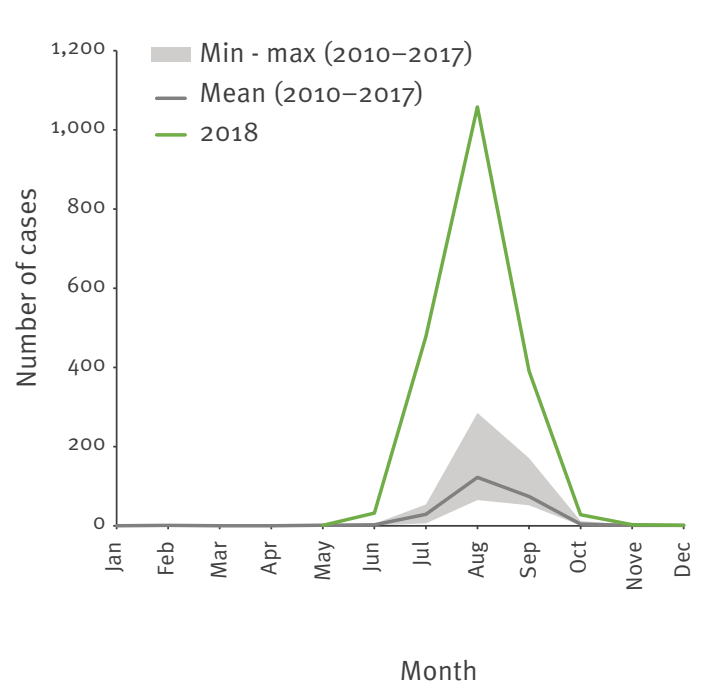

EU: European Union.

a Where month of disease onset was missing, we used month of diagnosis or month of notification $(n=138)$.

and ultimately the month of notification. Statistical analyses were conducted using STATA/IC version 13.0 (Stata Corp., College Station, United States). Maps were produced using the ECDC Map maker (EMMa) (ECDC, Solna, Sweden) [21].

\section{Results}

\section{Epidemiological summary}

Between 2010 and 2018, 13 EU countries (Austria, Bulgaria, Croatia, Cyprus, Czechia, France, Greece, Hungary, Italy, Portugal, Romania, Slovenia and Spain) and five EU enlargement countries (Albania, Montenegro, Serbia, Turkey and Kosovo*) reported 3,849 cases of human WNV infections with known clinical manifestation and place of infection (Table 1). Among these, 2,804 (73\%) were WNND cases, 906 (24\%) were WNF cases and 139 (4\%) were asymptomatic (Table 2). In addition, 132 cases were reported that were excluded from the study because of missing information on exact place of infection and clinical manifestation. Greece $(n=978 ; 25 \%)$ and Italy $(n=971$; $25 \%$ reported the highest numbers of WNV infections with known clinical manifestation and place of infection, followed by Serbia $(n=613 ; 16 \%)$. Confirmed cases accounted for $78 \%$ of the cases (ranging from $50 \%$ in 2010 to $89 \%$ in 2016) and the proportion of confirmed cases increased over time.

The yearly number of reported WNV infections fluctuated, with peaks observed in $2010(n=391)$ and 2018 $(n=1,993)$ (Table 1). In 2010, Greece $(n=262 ; 67 \%)$ and
Romania $(n=57 ; 15 \%)$ reported the highest number of cases. In 2018, Italy $(n=610 ; 31 \%)$, Serbia $(n=415$; $21 \%)$ and Greece $(n=311 ; 16 \%)$ reported the highest number of cases. For the majority of the countries, 2018 was the year when the highest number of cases was reported. Between 2010 and 2018, 2,804 WNND cases were reported. Greece $(n=709 ; 25 \%)$, Romania $(n=598 ; 21 \%)$ and Serbia $(n=544 ; 19 \%)$ reported the majority of the WNND cases. The annual proportion of WNND cases ranged from $68 \%$ in 2018 to $82 \%$ in 2014 . The proportion of cases with WNF ranged from $12 \%$ in 2015 and 2016 to $32 \%$ in 2012. Asymptomatic cases were reported between 2011 and 2018 and ranged between $0.67 \%$ in 2011 and $10 \%$ in 2015 .

Between 2010 and 2018, 379 deaths among cases of WNV infection were reported (Table 1). The CF among WNND cases ranged from $3.4 \%$ in 2015 to $16 \%$ in 2010. The highest total CF among WNND cases were observed in Czechia (1/3), followed by Kosovo* (3/12) and Turkey (15/64), although the number of cases was very low limiting the interpretation of this CF.

\section{Demographic characteristics}

The overall male:female ratio ( $M: F$ ratio) was 1.5:1, ranging from 1.3 in 2010 and 2012 to 2.7 in 2015. The M:F ratio among WNND cases was 1.6:1. The median age of cases of WNV infection was 66 years (interquartile range (IQR): $52-76$ ) (Table 2), while the median age of cases with WNND was 69 years (IQR: $57-77$ ). The median age of female and male cases of WNV infection was comparable. Between 2010 and 2018, the overall 


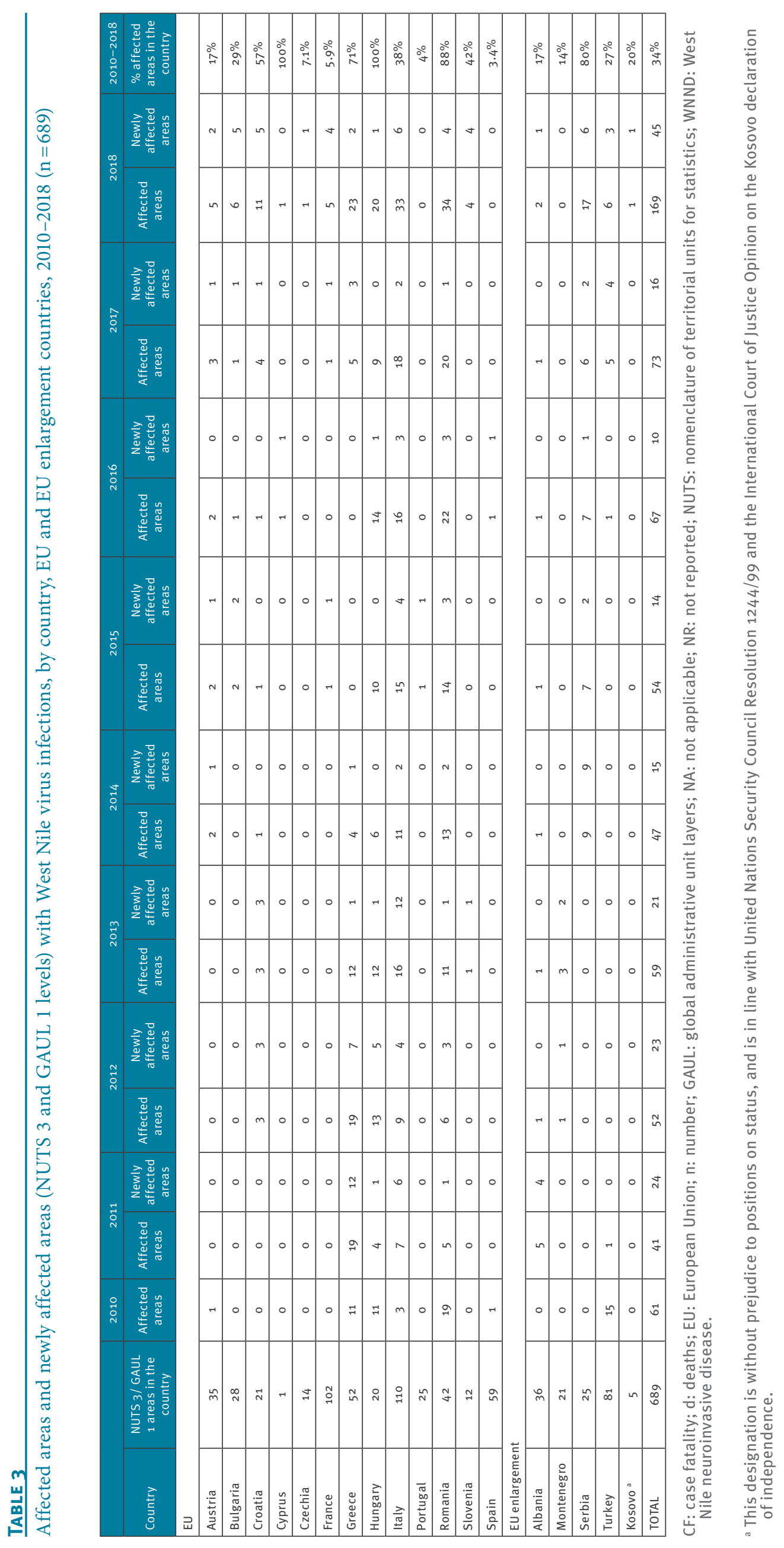




\section{FIGURE 2}

Geographical distribution of cases of West Nile virus infection by affected areas (NUTS 3 level or GAUL 1) and year, EU and EU enlargement countries, 2010-2018 ( $n=3,849)$

\section{A. $2010(n=391)$}

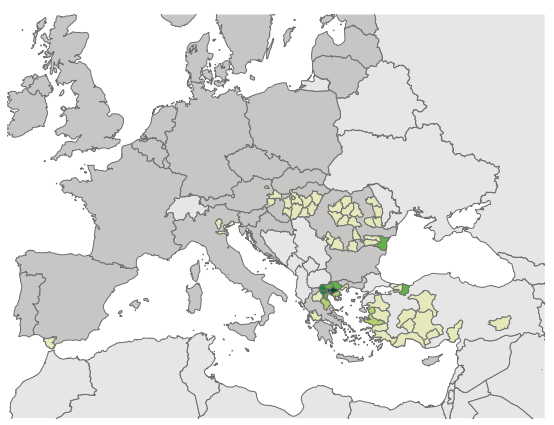

\section{D. $2013(n=248)$}

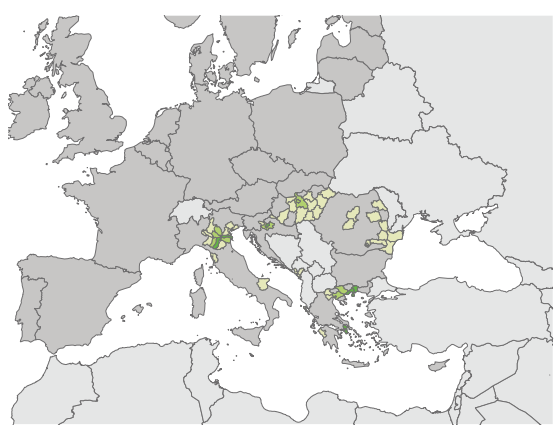

G. $2016(n=268)$

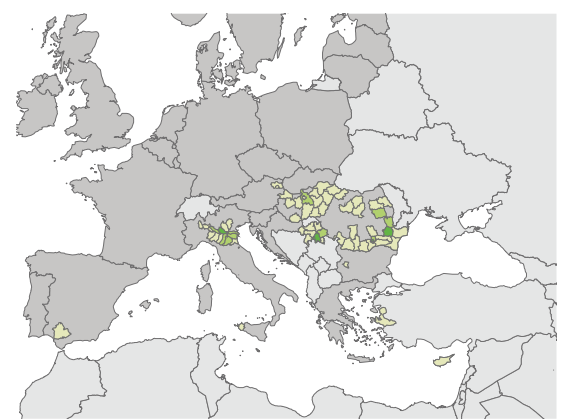

\section{B. $2011(n=149)$}

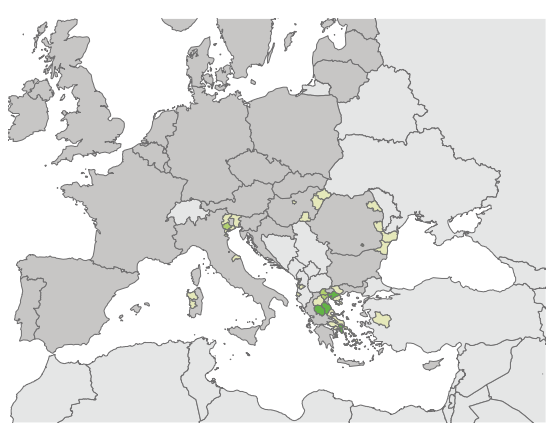

E. $2014(n=152)$

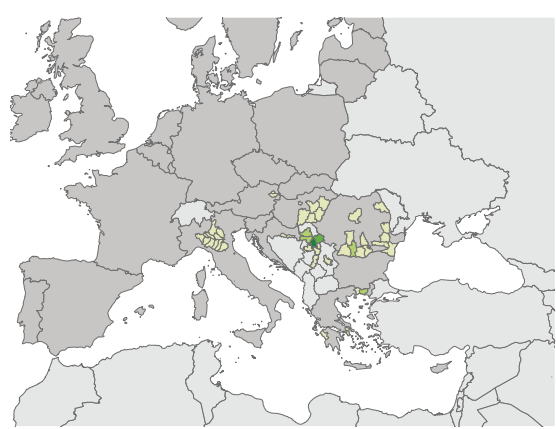

H. $2017(n=257)$

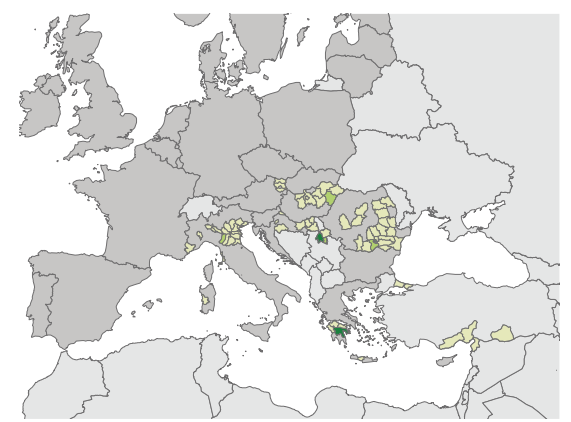

\section{C. $2012(n=241)$}

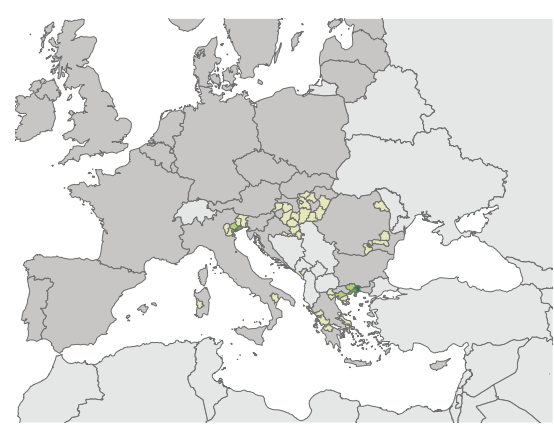

\section{F. $2015(n=150)$}

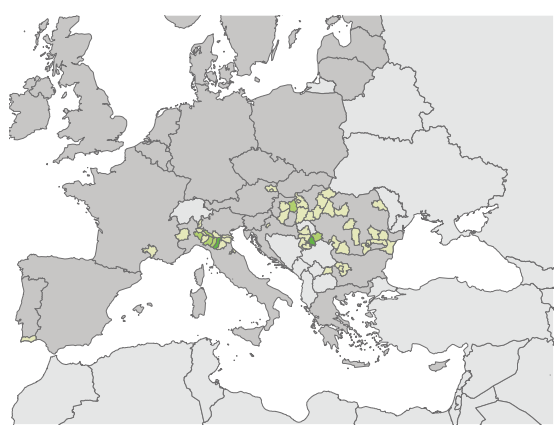

\section{I. $2018(n=1,993)$}

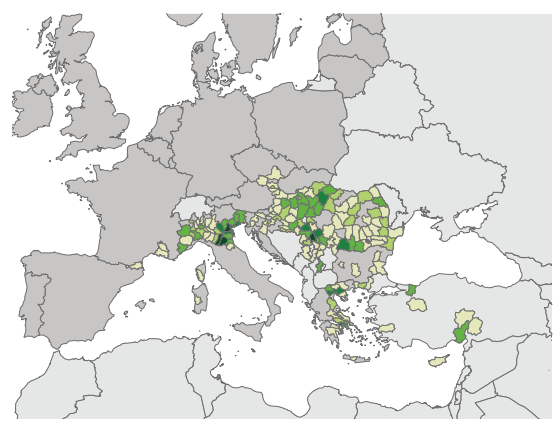

Maps produced on: 21 Nov 2019. Administrative boundaries: ${ }^{\circledR}$ EuroGeographics, ${ }^{\circledR U N-F A O}$

Number of West Nile virus infections per affected area

$\square 1-5 \square 6-10 \square 11-30 \square 31-60 \square>60$

GAUL: global administrative unit layers; EU: European Union; NUTS: nomenclature of territorial units for statistics.

median age was 66 years for both female and male cases (Table 2).

\section{Trend and seasonality}

The month of disease onset was available for $96 \%$ of the cases. Alternate dates such as month of diagnosis and month of notification were used for $3.6 \%$ and $0.026 \%$ of the cases, respectively. WNV transmission followed a seasonal pattern: most infections occurred from early summer to early autumn, with a clear peak in August (Figure 1). In 2018, the transmission season was longer than in previous years, starting in week 22, about 2 weeks earlier than usual and lasting until week 49 , around 9 weeks longer than usual.

\section{Geographical distribution}

The number of affected countries increased from seven countries in 2010 to 15 in 2018. Generally, when the 
number of reported infections increased, the number of affected areas increased accordingly. On average, 57 NUTS 3 areas were affected every year between 2010 and 2017 (range: 41-72), whereas in 2018, 169 areas were affected (Table 3).

Over the study period, some affected countries detected a wide spread of WNV infections across the country. Especially in 2018 when WNV infections were more widely distributed than in previous years, cases were reported from the whole of Hungary and large parts of Romania, Serbia and Greece (Figure 2 and Table 3). However, other countries reported only a limited spread until the time of writing of this report, such as Spain, Portugal and France. Every year, new areas were affected (Table 3). Between 2011 and 2017, there were on average 18 (range: 10-24) newly affected areas annually. In comparison, 45 areas were newly affected in 2018 .

\section{Discussion}

Between 2010 and 2018, cases of WNV infection were reported every year with peaks in the number of cases in 2010 and 2018. This pattern resembles the WNV pattern in North America, where infections have been reported every year since it first emerged in 1999 and major outbreaks occur in certain years [22,23]. In 2018, Europe faced its largest WNV outbreak, with more cases reported in 2018 than the cumulative number of cases reported between 2010 and 2017.

The intensity of WNV transmission in a given year is determined by the abundance of competent mosquitoes and the prevalence of infection in them [24]. Higher temperatures can shorten the extrinsic incubation period of the virus in the vector [25], increase the vector population's growth rate, accelerate the evolution rate of the virus and increase viral transmission to birds [26]. Increased precipitation positively correlates with disease outbreaks because of higher mosquito abundance, while drought may intensify bird-mosquito interaction around remaining water sources [25]. Weather conditions can also affect the reproduction patterns of the avian hosts [27-29]. For example, the date when the first eggs are laid can influence the number of nestlings in the beginning of the WNV transmission season and the number of broods within a season [27-29].

Increased intensity of virus circulation could be related to higher virulence of the circulating strains, leading to more severe disease and consequently more symptomatic infections. For example in Romania, in 2016 and 2017, an outbreak of WNND with high CF in humans was reported $[30,31]$. It followed the introduction of a new lineage 2 strain in the mosquito population in 2015 and its spread during the 2016 transmission season [30]. The circulating strain in 2018 , however, was genetically closely related to the strain circulating during previous years and, to our knowledge, had no markers of higher virulence [32-37].
Background immunity against flaviviruses such as WNV influences the intensity of outbreaks in an endemic area [38]. In populations with background immunity, the number of symptomatic humans and equids is lower [39] and the reduced susceptible human population has been posited in one study as one of the likely factors behind the absence of reported infections in Greece between 2015 and 2016 [40]. Birds recovering from a WNV infection usually develop long-term immunity [41,42]. Reduced herd immunity in birds (i.e. after an increase in immunologically naïve offspring) can increase the risk of more intense virus circulation [43]. For example, the first occurrence of WNV infections in North America in 1999 lead to a major WNV outbreak with more than 20,000 human cases. Birds in this area had no previous exposure to WNV before this outbreak and the lack of acquired and evolved immunity may have increased the intensity of the epidemic [44]. Furthermore, the enzootic cycle of WNV might be influenced by immunological cross-reactivity to other flaviviruses in the Japanese encephalitis virus serocomplex, such as Usutu virus. Co-circulation of West Nile and Usutu viruses in the same ecosystem has been described without evidence of cross protection or antibody-dependant enhancement [45], and the avian host spectrum of the two viruses might not be the same.

The total number of affected areas and the number of newly affected areas in 2018 was higher than in all previous years, suggesting an increased spread of WNV. Furthermore, in 2018, human cases of WNV infection were reported from countries such as Czechia and Slovenia that had not previously reported human WNV infections. Often newly affected areas border on areas already affected in previous years, suggesting that the virus spreads from affected areas to non-affected neighbouring areas. The weighted average of the number of affected areas in neighbouring areas affected in previous years has been described as a risk factor for WNV circulation [46].

In 2018, WNV was detected for the first time in birds and equids in five federal states in Germany, and locally acquired human infections were reported in 2019 [47,48]. This highlights that once the enzootic cycle of the virus is established, infections among accidental hosts (i.e. equids and humans) can be expected. We suggest that the spread of WNV in Europe is largely due to local movements of long-range migratory and resident birds, while migratory birds returning from their overwintering places in Africa or other regions probably played a minimal role in recent years as the virus is already endemic in Europe [49]. In 2010 in Romania, newly affected areas were known to be roosting places on bird migration pathways [50]. Overwintering of infected mosquitoes has an important role in the maintenance of WNV [51].

Changing weather conditions may affect migration patterns, and therefore the spread of the virus within 
Europe [25,52]. However, environmental and ecological conditions in Europe today are permissive for the overwintering and establishment of WNV strains [51] and the disease is considered endemic in the southern part of Europe. Genetic studies indicate that WNV infections after 2004 in central and southern Europe were predominantly caused by the descendants of the lineage 2 strain that emerged in 2004 and became endemic in the region $[10,11,40,48,51,53,54]$.

The role of a bird species in the enzootic cycle of the virus depends on the number of birds and attractiveness to mosquitoes as well as their physiological capacity for transmitting the infection to mosquito vectors [55]. The primary avian host species that maintain an enzootic cycle in Europe remain unknown [26]. Testing the serological status of captive and wild birds could be a useful indicator for the estimation of host susceptibility to WNV infections and more research is needed to identify the potential capacity of different bird species to contribute to WNV circulation.

Generally, the transmission season in Europe lasts from June to October, with a peak in August [56]. In 2018, Greece, Hungary, Italy, Romania and Serbia observed a high number of cases very early in the transmission season $[13,57]$. Furthermore, infections occurred until the end of November, which marked an extended transmission season.

The timing of WNV outbreaks may be influenced by the arrival of migratory birds in locations close to or along migration routes during spring migration and by the abundance of amplification hosts among local birds. These could within 2-3 months infect large portions of the vector population and subsequently pass the virus to humans by June to September in the same year [53]. In recent years, because of an early rise of the mean spring temperatures, several bird species have been migrating to their breeding grounds earlier than previously observed [25].

The fact that WNV can overwinter in adult Culex mosquitoes [58] could also explain an earlier start of the transmission season, as vertically infected diapausing mosquitoes that emerged at the end of the breeding season can initiate earlier transmission in the following spring. Because many WNV infections remain asymptomatic, only a fraction is captured by surveillance. Considering that WNND reflects less than $1 \%$ of the total WNV infections [1], it can be estimated that the actual number of infections between 2010 and 2018 was at least 280,400.

The way countries conduct surveillance varies. For instance, some countries reported all WNV infections, others only WNND cases. Some countries reported all confirmed and probable cases, others only the confirmed. The percentage of confirmed cases increased over time, which may suggest improving laboratory capacity/capability in some countries. Some countries also reported cases that were laboratory-confirmed by urine testing, although this is currently not included in the EU case definition. Furthermore, some countries actively monitor and report the final outcome, while others do not, which can compromise the validity of CF estimations and lead to underestimation. The ability to report the outcome of cases only when it is clinically attributable to WNV infections is complex, therefore CF could be overestimated in countries reporting all deaths among patients diagnosed with WNV infection. Only few countries performed continuous monitoring of WNV infections among blood donors and reported asymptomatic infections (Greece reported its first asymptomatic case in 2011, Montenegro in 2013, Austria and Italy in 2015, and Croatia and France in 2018). Furthermore, only the numbers of cases with known clinical manifestations and place of infection were analysed here. Variations in the countries' reporting completeness limit the validity of direct comparisons.

Improved sensitivity of national surveillance systems, increased diagnostic capacity, more testing following greater awareness of WNV, and the introduction of testing of blood donors could have influenced the yearly number of cases. Furthermore, changes in blood donor screening practice could have influenced the proportion of detected asymptomatic infections, which however was very low in this study.

Asymptomatic cases are usually fortuitous detections through blood donor screenings and do not reflect the true proportion of asymptomatic cases. The proportion of asymptomatic cases detected and reported is small but not negligible. In previously affected or endemic areas in Greece and Italy, positive blood donors have been reported before the diagnosis of symptomatic cases [59]. WNV has also been detected in blood donors originating from areas where the WNV prevalence in humans is low [60]. This highlights the importance of enhanced vigilance and early warning to ensure the timely identification of WNV circulation and affected areas in each transmission season.

As no specific treatment or vaccine against WNV infection is available for humans, prevention relies to a high degree on personal protective measures against mosquito bites [61]. The effectiveness of different vector control strategies against competent WNV-vector mosquitoes requires further investigation. In addition, a better understanding of the mosquito distribution, host biting preference and species hybridisation will improve knowledge of WNV persistence and the risk to human populations [54]. Comparing whole genome sequences of WNV detected in asymptomatic people (blood donors), patients, animal hosts and vectors may help identify more virulent viral strains and better explain the evolution of the virus and its historical introductions and subsequent spread in Europe. 


\section{Conclusion}

Real-time surveillance of WNV infections is key to ensuring that clinicians and public health authorities receive early warning about the occurrence of cases and potential unusual seasonal patterns. This ensures that safety measures are implemented in a timely manner to avoid infections through SoHO.

Understanding the factors that influence WNV ecology and transmission is crucial when trying to predict the risk of increased WNV activity in a season, its geographical distribution and the expected scale of human infections, also at local level. Public health authorities in currently unaffected countries need to be aware that human cases may appear shortly after the first detection of animal cases and should develop preparedness plans before the occurrence of human WNV infections. ConclusionGo to section...

Real-time surveillance of WNV infections is key to ensuring that clinicians and public health authorities receive early warning about the occurrence of cases and potential unusual seasonal patterns. This ensures that safety measures are implemented in a timely manner to avoid infections through SoHO.

Understanding the factors that influence WNV ecology and transmission is crucial when trying to predict the risk of increased WNV activity in a season, its geographical distribution and the expected scale of human infections, also at local level. Public health authorities in currently unaffected countries need to be aware that human cases may appear shortly after the first detection of animal cases and should develop preparedness plans before the occurrence of human WNV infections.

\section{*Note}

This designation is without prejudice to positions on status, and is in line with United Nations Security Council Resolution $1244 / 99$ and the International Court of Justice Opinion on the Kosovo declaration of independence.

\section{**Authors' correction}

On request of the authors, the sentence "The virus is primarily transmitted through the bites of infected mosquitoes, mainly of the Culex genus, but occasionally also through transfusion/transplantation of substances of human origin (SoHO) (i.e. blood, organs or cells), percutaneous exposure or inhalation in laboratories, or transplacental passage from mother to fetus" was changed to "The virus is primarily transmitted through the bites of infected mosquitoes, mainly of the Culex genus, but occasionally also through transfusion/transplantation of substances of human origin ( $\mathrm{SoHO})$ (i.e. blood, organs or cells), percutaneous or conjunctival exposure in laboratories, or transplacental passage from mother to fetus. This change was made on 20 May 2021.

\section{Acknowledgements}

The authors would like to thank:
Hector Honrubia Huertas (ECDC) for his support with the preparation of the maps.

The National Focal points for Emerging and Vector-borne Diseases for their support and contribution of national West Nile virus surveillance data.

Tibor Csörgő (Eötvös Loránd University, Budapest, Hungary) for his scientific support on ornithological aspects of WNV epidemiology.

Antonino Bella (Epidemiology Unit, Department of Infectious Diseases, Istituto Superiore di Sanità (ISS), Rome, Italy); Giulietta Venturi (Italian National Reference Laboratory for Arboviruses, Department of Infectious Diseases, ISS Rome, Italy); Marco Di Luca (Medical entomology team, Department of Infectious Diseases, ISS Rome, Italy), Francesco Maraglino (Italian Ministry of Health), and physicians, staff of regional reference laboratories, and of regional and local public health authorities, for their contribution to the enhanced surveillance of human WNV infection in Italy.

Annita Vakali and Theano Georgakopoulou (Hellenic National Public Health Organization, Athens, Greece), Prof. Anna Papa (National Reference Centre for Arboviruses, Thessaloniki, Greece), and physicians, staff of other collaborating laboratories (Medical Schools of Athens and Crete and Hellenic Pasteur Institute), and staff of national and regional public health authorities, for their contribution to the enhanced surveillance of WNV infection in Greece.

\section{Conflict of interest}

None declared.

\section{Authors' contributions}

CMG, JJY and JMH developed the study protocol. JJY and JMH analysed the data and drafted the manuscript. CMG and TB contributed to the interpretation of data and to the writing of the manuscript. SWA, DP, FR and NS provided data and contributed to the interpretation of data. All authors revised the manuscript critically and approved the final version.

\section{References}

1. Petersen LR, Brault AC, Nasci RS. West Nile virus: review of the literature. JAMA. 2013;310(3):308-15. https://doi.org/10.1001/ jama.2013.8042 PMID: 23860989

2. Bowen RA, Nemeth NM. Experimental infections with West Nile virus. Curr Opin Infect Dis. 2007;20(3):293-7. https://doi. org/10.1097/QCO.ob013e32816b5cad PMID: 17471040

3. Kramer LD, Li J, Shi PY. West Nile virus. Lancet Neurol. 2007;6(2):171-81. https://doi.org/10.1016/S14744422(07)70030-3 PMID: 17239804

4. Lim SM, Koraka P, Osterhaus ADME, Martina BEE. West Nile virus: immunity and pathogenesis. Viruses. 2011;3(6):811-28. https://doi.org/10.3390/v3060811 PMID: 21994755

5. Bardos V, Adamcova J, Dedei S, Gjini N, Rosicky B, Simkova A. Neutralizing antibodies against some neurotropic viruses determined in human sera in Albania. J Hyg Epidemiol Microbiol Immunol. 1959;3:277-82. PMID: 13796704

6. Hubálek Z, Halouzka J. West Nile fever--a reemerging mosquitoborne viral disease in Europe. Emerg Infect Dis. 1999;5(5):64350. https://doi.org/10.3201/eid0505.990505 PMID: 10511520

7. Chaskopoulou A, L'Ambert G, Petric D, Bellini R, Zgomba $M$, Groen TA, et al. Ecology of West Nile virus across four European countries: review of weather profiles, vector population dynamics and vector control response. Parasit Vectors. 2016;9(1):482. https://doi.org/10.1186/s13071-016 1736-6 PMID: 27590848

8. Rizzo C, Napoli C, Venturi G, Pupella S, Lombardini L, Calistri P, et al. West Nile virus transmission: results from the integrated 
Surveillance system in Italy, 2008 to 2015. Euro Surveill. 2016;21(37):30340. https://doi.org/10.2807/1560-7917. ES.2016.21.37.30340 PMID: 27684046

9. Petrović T, Blázquez AB, Lupulović D, Lazić G, EscribanoRomero E, Fabijan D, et al. Monitoring West Nile virus (WNV) infection in wild birds in Serbia during 2012: first isolation and characterisation of WNV strains from Serbia. Euro Surveill. 2013;18(44):20622. https://doi.org/10.2807/1560-7917. ES2013.18.44.20622 PMID: 24176657

10. Bakonyi T, Ferenczi E, Erdélyi K, Kutasi O, Csörgő T, Seidel B, et al. Explosive spread of a neuroinvasive lineage 2 West Nile virus in Central Europe, 2008/2009. Vet Microbiol. 2013:165(1 2):61-70. https://doi.org/10.1016/j.vetmic.2013.03.005 PMID: 23570864

11. Papa A, Xanthopoulou K, Gewehr S, Mourelatos S. Detection of West Nile virus lineage 2 in mosquitoes during a human outbreak in Greece. Clin Microbiol Infect. 2011;17(8):117680. https://doi.org/10.1111/j.1469-0691.2010.03438.x PMID: 21781205

12. Zehender G, Veo C, Ebranati E, Carta V, Rovida F, Percivalle $\mathrm{E}$, et al. Reconstructing the recent West Nile virus lineage 2 epidemic in Europe and Italy using discrete and continuous phylogeography. PLoS One. 2017;12(7):e0179679. https://doi. org/10.1371/journal.pone.0179679 PMID: 28678837

13. Haussig JM, Young JJ, Gossner CM, Mezei E, Bella A, Sirbu A, et al. Early start of the West Nile fever transmission season 2018 in Europe. Euro Surveill. 2018;23(32):1800428. https:// doi.org/10.2807/1560-7917.ES.2018.23.32.1800428 PMID: 30107869

14. Gossner CM, Marrama L, Carson M, Allerberger F, Calistri $P$, Dilaveris D, et al. West Nile virus surveillance in Europe: moving towards an integrated animal-human-vector approach. Euro Surveill. 2017;22(18):30526. https://doi. org/10.2807/1560-7917.ES.2017.22.18.30526 PMID: 28494844

15. European Commission. Commission Decision of 18 December 2007 amending Decision No 2119/98/EC of the European Parliament and of the Council and Decision 2000/96/EC as regards communicable diseases listed in those decisions Brussels: Official Journal of the European Union; 2007. Available from: https://eur-lex.europa.eu/legal-content/EN/ TXT/PDF/?uri=CELEX:32007D0875\&from =EN

16. Dente MG, Riccardo F, Bolici F, Colella NA, Jovanovic V, Drakulovic M, et al. Implementation of the One Health approach to fight arbovirus infections in the Mediterranean and Black Sea Region: Assessing integrated surveillance in Serbia, Tunisia and Georgia. Zoonoses Public Health. 2019;66(3):276-87. https://doi.org/10.1111/zph.12562 PMID: 30724030

17. European Commission. Commission Directive 2014/110/EU of 17 December 2014 amending Directive 2004/33/EC as regards temporary deferral criteria for donors of allogeneic blood donations. Brussels: Official Journal of the European Union; 2014. Available from: http://eur-lex.europa.eu/legal-content/ $\mathrm{EN} / \mathrm{TXT} / \mathrm{PDF} /$ ?uri=CELEX:32014Lo110\&from $=\mathrm{EN}$

18. European Commission. European Commission. Commission implementing decision (EU) $2018 / 945$ of 22 June 2018 on the communicable diseases and related special health issues to be covered by epidemiological surveillance as well as relevant case definitions. Brussels: Official Journal of the European Union; 2018. Available from: https://eur-lex.europa.eu/ legal-content/EN/TXT/PDF/?uri=CELEX:32018D0945\&from=EN

19. Statistical Office of the European Communities (Eurostat). NUTS - Nomenclature of Territorial Units for Statistics. Background. Brussels: Eurostat. [Accessed: 25 Jan 2019]. Available from: http://ec.europa.eu/eurostat/web/nuts/ overview

20. GeoNetwork. Global Administrative Unit Layers (GAUL). Food and Agriculture Organization of the United Nations. [Accesssed: 25 Feb 2019]. Available from: http://www.fao.org/ geonetwork/srv/en/metadata.show?id=12691

21. European Centre for Disease Prevention and Control (ECDC). ECDC Map Maker Tool (EMMa). Stockholm: ECDC. [Accessed: 25 Feb 2020]. Available from: https://www.ecdc.europa.eu/en/ publications-data/ecdc-map-maker-tool-emma

22. Barrett ADT. West Nile in Europe: an increasing public health problem. J Travel Med. 2018;25(1). https://doi.org/10.1093/ jtm/tayog6 PMID: 30289526

23. Chancey C, Grinev A, Volkova E, Rios M. The global ecology and epidemiology of West Nile virus. BioMed Res Int. 2015;2015:376230. https://doi.org/10.1155/2015/376230 PMID: 25866777

24. Hayes EB, Komar N, Nasci RS, Montgomery SP, O’Leary DR, Campbell GL. Epidemiology and transmission dynamics of West Nile virus disease. Emerg Infect Dis. 2005;11(8):1167-73. https://doi.org/10.3201/eid1108.050289a PMID: 16102302
25. Paz S. Climate change impacts on West Nile virus transmission in a global context. Philos Trans R Soc Lond B Biol Sci. 2015;370(1665):20130561. https://doi.org/10.1098/ rstb.2013.0561 PMID: 25688020

26. Paz S, Semenza JC. Environmental drivers of West Nile fever epidemiology in Europe and Western Asia--a review. Int J Environ Res Public Health. 2013;10(8):3543-62. https://doi. org/10.3390/ijerph10083543 PMID: 23939389

27. Gienapp P, Visser ME. Possible fitness consequences of experimentally advanced laying dates in Great Tits: differences between populations in different habitats. Funct Ecol. 2006;20(1):180-5. https://doi. org/10.1111/j.1365-2435.2006.01079.x

28. Rubolini D, Ambrosini R, Caffi M, Brichetti P, Armiraglio S, Saino N. Long-term trends in first arrival and first egg laying dates of some migrant and resident bird species in northern Italy. Int J Biometeorol. 2007;51(6):553-63. https://doi. org/10.1007/s00484-007-0094-7 PMID: 17375338

29. Samplonius JM, Bartošová L, Burgess MD, Bushuev AV, Eeva T, Ivankina EV, et al. Phenological sensitivity to climate change is higher in resident than in migrant bird populations among European cavity breeders. Glob Change Biol. 2018;24(8):378090. https://doi.org/10.1111/gcb.14160 PMID: 29691942

30. Cotar AI, Falcuta E, Prioteasa LF, Dinu S, Ceianu CS, Paz S. Transmission dynamics of the West Nile virus in mosquito vector populations under the influence of weather factors in the Danube Delta, Romania. EcoHealth. 2016;13(4):796-807. https://doi.org/10.1007/S10393-016-1176-y PMID: 27709311

31. Popescu CP, Florescu SA, Cotar AI, Badescu D, Ceianu CS, Zaharia M, et al. Re-emergence of severe West Nile virus neuroinvasive disease in humans in Romania, 2012 to 2017-implications for travel medicine. Travel Med Infect Dis. 2018;22:30-5. https://doi.org/10.1016/j.tmaid.2018.03.001 PMID: 29544774

32. Veo C, Della Ventura C, Moreno A, Rovida F, Percivalle E, Canziani $S$, et al. Evolutionary dynamics of the lineage 2 West Nile virus that caused the largest European epidemic: Italy 2011-2018. Viruses. 2019;11(9):E814. https://doi.org/10.3390/ V11090814 PMID: 31484295

33. Chaintoutis SC, Papa A, Pervanidou D, Dovas Cl. Evolutionary dynamics of lineage 2 West Nile virus in Europe, 2004-2018: Phylogeny, selection pressure and phylogeography. Mol Phylogenet Evol. 2019;141:106617. https://doi.org/10.1016/j. ympev.2019.106617 PMID: 31521822

34. Nagy A, Mezei E, Nagy O, Bakonyi T, Csonka N, Kaposi M, et al. Extraordinary increase in West Nile virus cases and first confirmed human Usutu virus infection in Hungary, 2018. Euro Surveill. 2019;24(28):1900038. https://doi.org/10.2807/15607917.ES.2019.24.28.1900038 PMID: 31311619

35. Michel F, Sieg M, Fischer D, Keller M, Eiden M, Reuschel M, et al. Evidence for West Nile virus and Usutu virus infections in wild and resident birds in Germany, 2017 and 2018. Viruses. 2019;11(7):E674. https://doi.org/10.3390/v11070674 PMID: 31340516

36. Čabanová V, Šikutová S, Straková P, Šebesta O, Vichová B, Zubríková D, et al. Co-Circulation of West Nile and Usutu Flaviviruses in Mosquitoes in Slovakia, 2018. Viruses. 2019;11(7):E639. https://doi.org/10.3390/v11070639 PMID: 31336825

37. Vilibic-Cavlek T, Savic V, Sabadi D, Peric L, Barbic L, Klobucar A, et al. Prevalence and molecular epidemiology of West Nile and Usutu virus infections in Croatia in the 'One health' context, 2018. Transbound Emerg Dis. 2019;66(5):1946-57. https://doi.org/10.1111/tbed.13225 PMID: 31067011

38. Meister T, Lussy H, Bakonyi T, Sikutová S, Rudolf I, Vogl W, et al. Serological evidence of continuing high Usutu virus (Flaviviridae) activity and establishment of herd immunity in wild birds in Austria. Vet Microbiol. 2008;127(3-4):237-48. https://doi.org/10.1016/j.vetmic.2007.08.023 PMID: 17869454

39. Campbell GL, Marfin AA, Lanciotti RS, Gubler DJ. West Nile virus. Lancet Infect Dis. 2002;2(9):519-29. https://doi. org/10.1016/S1473-3099(02)00368-7 PMID: 12206968

40. Mavrouli M, Vrioni G, Kapsimali V, Tsiamis C, Mavroulis S, Pervanidou D, et al. Reemergence of West Nile virus infections in southern Greece, 2017. Am J Trop Med Hyg. 2019;100(2):4206. https://doi.org/10.4269/ajtmh.18-0339 PMID: 30526732

41. Nemeth NM, Oesterle PT, Bowen RA. Humoral immunity to West Nile virus is long-lasting and protective in the house sparrow (Passer domesticus). Am J Trop Med Hyg. 2009;80(5):864-9. https://doi.org/10.4269/ajtmh.2009.80.864 PMID: 19407139

42. Nemeth NM, Kratz GE, Bates R, Scherpelz JA, Bowen RA, Komar N. Naturally induced humoral immunity to West Nile virus infection in raptors. EcoHealth. 2008;5(3):298-304. https:// doi.org/10.1007/s10393-008-0183-Z PMID: 18677535

43. Kwan JL, Kluh S, Reisen WK. Antecedent avian immunity limits tangential transmission of West Nile virus to humans. PLoS 
One. 2012;7(3):e34127. https://doi.org/10.1371/journal. pone.0034127 PMID: 22457819

44. Kilpatrick AM, Kramer LD, Jones MJ, Marra PP, Daszak P. West Nile virus epidemics in North America are driven by shifts in mosquito feeding behavior. PLoS Biol. 2006;4(4):e82. https:// doi.org/10.1371/journal.pbio.0040082 PMID: 16494532

45. Rudolf I, Bakonyi T, Šebesta O, Mendel J, Peško J, Betášová L, et al. Co-circulation of Usutu virus and West Nile virus in a reed bed ecosystem. Parasit Vectors. 2015;8(1):520. https://doi. org/10.1186/s13071-015-1139-0 PMID: 26459018

46. Tran A, Sudre B, Paz S, Rossi M, Desbrosse A, Chevalier $\mathrm{V}$, et al. Environmental predictors of West Nile fever risk in Europe. Int J Health Geogr. 2014;13(1):26. https://doi. org/10.1186/1476-072X-13-26 PMID: 24986363

47. Robert Koch Institut (RKI). Weitere in Deutschland übertragene Fälle von West-Nil-Virus-Infektion. [Further cases of West Nile virus infection transmitted in Germany]. Berlin: RKI; 2019. German. Available from: https://www.rki.de/DE/Content/ Infekt/EpidBull/Archiv/2019/43/Art_02.html

48. Ziegler U, Lühken $R$, Keller M, Cadar D, van der Grinten E, Michel F, et al. West Nile virus epizootic in Germany, 2018 Antiviral Res. 2019;162:39-43. https://doi.org/10.1016/j. antiviral.2018.12.005 PMID: 30550796

49. Seidowski D, Ziegler U, von Rönn JA, Müller K, Hüppop $\mathrm{K}$, Müller T, et al. West Nile virus monitoring of migratory and resident birds in Germany. Vector Borne Zoonotic Dis. 2010;10(7):639-47. https://doi.org/10.1089/vbz.2009.0236 PMID: 20854016

50. Sirbu A, Ceianu CS, Panculescu-Gatej RI, Vazquez A, Tenorio $A$, Rebreanu R, et al. Outbreak of West Nile virus infection in humans, Romania, July to October 2010. Euro Surveill. 2011;16(2):19762. https://doi.org/10.2807/ese.16.02.19762-en PMID: 21251489

51. Rudolf I, Betášová L, Blažejová H, Venclíková K, Straková P, Šebesta 0, et al. West Nile virus in overwintering mosquitoes, central Europe. Parasit Vectors. 2017;10(1):452. https://doi. org/10.1186/S13071-017-2399-7 PMID: 28969685

52. Mori H, Wu J, Ibaraki M, Schwartz FW. Key factors influencing the incidence of West Nile virus in Burleigh County, North Dakota. Int J Environ Res Public Health. 2018;15(9):1928. https://doi.org/10.339o/ijerph15091928 PMID: 30189592

53. Calistri P, Giovannini A, Hubalek Z, Ionescu A, Monaco F, Savini G, et al. Epidemiology of west nile in europe and in the mediterranean basin. Open Virol J. 2010;4(1):29-37. https:// doi.org/10.2174/1874357901004010029 PMID: 20517490

54. Hernández-Triana LM, Jeffries CL, Mansfield KL, Carnell G, Fooks AR, Johnson N. Emergence of west nile virus lineage 2 in europe: a review on the introduction and spread of a mosquitoborne disease. Front Public Health. 2014;2:271. https://doi. org/10.3389/fpubh.2014.00271 PMID: 25538937

55. Kain MP, Bolker BM. Predicting West Nile virus transmission in North American bird communities using phylogenetic mixed effects models and eBird citizen science data. Parasit Vectors. 2019;12(1):395. https://doi.org/10.1186/s13071-019-3656-8 PMID: 31395085

56. European Centre for Disease Prevention and Control (ECDC). West Nile virus infection. In: ECDC. Annual epidemiological report for 2017. Stockholm: ECDC; 2019. Available from: https://www.ecdc.europa.eu/sites/default/files/documents/ AER_for_2017-West-Nile-virus-infection.pdf

57. Riccardo F, Monaco F, Bella A, Savini G, Russo F, Cagarelli R, et al. An early start of West Nile virus seasonal transmission: the added value of One Heath surveillance in detecting early circulation and triggering timely response in Italy, June to July 2018. Euro Surveill. 2018;23(32):1800427. https:// doi.org/10.2807/1560-7917.ES.2018.23.32.1800427 PMID 30107870

58. Nasci RS, Savage HM, White DJ, Miller JR, Cropp BC, Godsey MS, et al. West Nile virus in overwintering Culex mosquitoes, New York City, 2000. Emerg Infect Dis. 2001;7(4):742-4. https://doi.org/10.3201/eido704.017426 PMID: 11585542

59. Domanović D, Gossner CM, Lieshout-Krikke R, Mayr W, BarotiToth K, Dobrota AM, et al. West Nile and Usutu virus infections and challenges to blood safety in the European Union. Emerg Infect Dis. 2019;25(6):1050-7. https://doi.org/10.3201/ eid2506.181755 PMID: 31107223

6o. Kolodziejek J, Seidel B, Jungbauer C, Dimmel K, Kolodziejek $M$, Rudolf I, et al. West Nile virus positive blood donation and subsequent entomological investigation, Austria, 2014. PLoS One. 2015;10(5):e0126381. https://doi.org/10.1371/journal. pone.0126381 PMID: 25961567

61. European Centre for Disease Prevention and Control (ECDC). Factsheet about West Nile virus infection. Stockholm: ECDC. [Accessed: 25 Feb 2020]. Available from: https://www.ecdc.europa.eu/en/west-nile-fever/facts/ factsheet-about-west-nile-fever
License, supplementary material and copyright

This is an open-access article distributed under the terms of the Creative Commons Attribution (CC BY 4.0) Licence. You may share and adapt the material, but must give appropriate credit to the source, provide a link to the licence and indicate if changes were made.

Any supplementary material referenced in the article can be found in the online version.

This article is copyright of the authors or their affiliated institutions, 2021. 